\title{
Jan Majer
}

Instytut Anglistyki, Uniwersytet Lódzlki

\section{ANALIZA DYSKURSU NA LEKCJI JĘZYKA OBCEGO}

\section{Discourse analysis in the foreign language classroom}

This paper outlines relevant issues in analyzing foreign language classroom communication patterns. Following a brief theoretical and historical background, it proceeds to discuss technical aspects of data collection and elaboration. Recording interaction between teachers and students is difficult but it later leads to an even more challenging task of transcribing talk. For this purpose, the article offers model instances of different traditions in compiling transcripts. However, the bulk of the present text is devoted to the exemplification of different applications of analysis of educational discourse. The samples, drawn from classroom interactions involving English, French and Polish as L2, illustrate topics such as corrective feedback, metatalk, the use of L1, and teacher questions. At the end, recommendations are given regarding further explorations and readings.

\section{Wprowadzenie}

Niniejszy artykuł ma na celu zwięzły opis analizy interakcji na lekcji języka obcego - narzędzia używanego przez specjalistów w zakresie językoznawstwa stosowanego posługujących się jakościowym paradygmatem badań. Metodologia ta godzi podejście lingwistyczne, wywodzące się z etnografii komunikacji, z podejściem pedagogicznym, którego nadrzędnym zadaniem jest szkolenie i doskonalenie zawodowe nauczycieli języków obcych. Po wstępie teoretycznym na temat historii badań nad dyskursem lekcyjnym omówione zostaną pokrótce warunki pobierania danych oraz techniki sporządzania transkrypcji zarejestrowanych interakcji. Zasadniczą część artykułu stanowi przegląd ważniejszych aplikacji analizy komunikacji na lekcji języka obcego. 


\section{Różne podejścia do analizy dyskursu lekcyjnego - krótki rys historyczno-problemowy}

Na początek wypada stwierdzić, iż zanim dyskursem edukacyjnym na dobre zajęli się teoretycy i praktycy metodyki nauczania języków obcych, był on przez lata przedmiotem dociekań przede wszystkim językoznawców. Zresztą zainteresowanie interakcją lekcyjną ze strony socjolingwistów i analityków dyskursu wydaje się naturalne. Jest to po prostu jedno z typowych zastosowań analizy konwersacyjnej w pracy z danymi pochodzącymi z tzw. kontekstów instytucjonalnych. Podobnie jak na sali sądowej czy w gabinecie lekarskim, dyskurs w klasie szkolnej przyjmuje formy wyraziste i przewidywalne, z dominacja jednej ze stron, odzwierciedlająca jej uprzywilejowanie i wynikające z niego niesymetryczne prawa uczestnictwa. Cechy te sprawiaja, że komunikacja lekcyjna jest intrygującym tematem licznych rozpraw naukowych i podręczników metodycznych.

Historia badań w omawianej dziedzinie sięga lat sześćdziesiątych, siedemdziesiątych i osiemdziesiątych ubiegłego wieku, z tym że pierwsze ważne prace, opublikowane przez autorów amerykańskich i brytyjskich - np. Bellack i in. (1966), Sinclair i Coulthard (1975), Sinclair i Brazil (1982) oraz Cazden (1988) bazowały przeważnie na danych pobranych podczas lekcji przedmiotów szkolnych nauczanych bez udziału języka obcego. Istotnym osiagnięciem tych pionierskich dokonań było nie tylko detaliczne opisanie struktury interakcji lekcyjnej, ze szczególnym uwzględnieniem swoistego rejestru zawodowego nazwanego z czasem mowa nauczyciela, lecz także skatalogowanie różnic między dyskursem edukacyjnym a zwykłą rozmowa. To właśnie pod wpływem wspomnianych wyżej prac zaczęto określać interakcję na lekcji języka obcego jako sztuczna. Wnioski z tych badań z cała pewnością inspirowały wczesne formy realizacji podejścia komunikacyjnego do nauczania języków obcych, tak radykalne w zwalczaniu przejawów nienaturalności w dyskursie pedagogicznym.

Dyskusja na temat autentyczności interakcji z udziałem nauczyciela i uczniów toczy się zatem już od wielu lat, i to zarówno w kręgach językoznawczych, jak i edukacyjnych. Na przykład van Lier (1984) przyznaje, że komunikacja na lekcji wcale nie musi wiernie naśladować spontanicznej rozmowy, z jaką spotykamy się w naturalnych sytuacjach poza kontekstem szkolnym. Jednak wobec takiej postawy metodyków wątpliwości rodzą się z kolei po stronie socjolingwistów, a mianowicie, czy interakcję w klasie należy w ogóle uznawać za odrębny typ dyskursu. I tak, w pracy Bernsteina (1990: 188) odnajdujemy takie oto kategoryczne stwierdzenie: dyskurs edukacyjny nie jest gatunkiem autonomicznym, ponieważ kontekst instytucjonalny szkoły jedynie nieco inaczej akcentuje i rozmieszcza te role, które występują już w innych rodzajach dyskursu. Zgoła odmienny pogląd odnajdujemy natomiast w artykule Nunna (1999). Czytamy tam, iż o autentyczności i odrębności gatunku interakcji typowej dla lekcji języka obcego świadczy dobitnie funkcja kierowania dyskursem przez nauczyciela. 
Autor jest zdania, że funkcja ta sama w sobie zasługuje na poważną analizę, na równi z krytycznymi cechami innych gatunków dyskursu (1999: 27).

$\mathrm{O}$ wiele mniej zasadniczy pogląd reprezentują interakcjoniści (na przykład Long i Sato 1983; Pica 1996). Wychodząc z przesłanek psycholingwistycznych i nie zajmując się statusem komunikacji na linii nauczyciel-uczeń, nauczycielklasa, uczeń-uczeń (bądź native-speaker-cudzoziemiec) w hierarchii gatunków dyskursu, badacze ci stawiają sobie za cel określenie tych cech interakcji, które moga korzystnie wpływać na proces przyswajania języka obcego. Są to takie czynniki jak na przykład zmodyfikowane dane wejściowe czy negocjowanie znaczenia. Wprawdzie tak rozumiana analiza interakcji ma nadal wiele elementów wspólnych z lingwistyczną analizą dyskursu, niemniej w centrum uwagi badaczy są tutaj przede wszystkim aspekty funkcjonalne poszczególnych wypowiedzi, a nie role tekstowe, które miałyby decydować, czy wypowiedzi te tworzą formalnie spójny i znaczeniowo koherentny dyskurs.

Nieodległa od wymienionej tradycji jest analiza dyskursu lekcyjnego uprawiana $\mathrm{w}$ celach metodycznych, a więc $\mathrm{z}$ zamiarem identyfikacji związków między interakcją a nauczaniem. Wykryte zależności zdają się świadczyć o tym, że proces nabywania kompetencji obcojęzycznej przebiega w drodze mediacji ze strony dyskursu (Seedhouse 2004). Kolejną aplikacją łączącą dydaktykę z teorią przyswajania języka obcego jest wyodrębnienie spośród wielu funkcji komunikacji lekcyjnej takich wypowiedzi, które mają charakter strategiczny, przy czym zachowania tego rodzaju zaobserwowano zarówno u uczniów (strategie uczenia się i strategie komunikacyjne), jak i u nauczycieli (strategie nauczania; por. Piotrowski 2006). Jeszcze innym ważnym nurtem badawczym jest analizowanie dyskursu na lekcji języka obcego jako komunikacji przebiegającej między uczestnikami tzw. bilingwalnej spoteczności ćniczeniowej (por. Sarangi i van Leeuwen 2003). W końcu to specyfika dyskursu dwujęzycznego najbardziej wyróżnia dydaktykę języka obcego na tle innych dydaktyk przedmiotowych. Niemałe zasługi położyli w tej mierze krajowi specjaliści z zakresu językoznawstwa stosowanego, dzięki czemu w dorobku tylko obecnej dekady jest kilka dłuższych opracowań poruszających między innymi taką właśnie tematykę: w kolejności chronologicznej - Majer (2003), Pawlak (2004), Piotrowski (2006), Niżegorodcew (2007) czy Łęska (2008). Książki te powstały na bazie korpusów danych zarejestrowanych na zajęciach z języka obcego z udziałem przede wszystkim polskich nauczycieli, uczniów i studentów.

\section{Zbieranie danych i obróbka materiału - warunki wstępne}

W krótkim z konieczności wstępie wspomniano o kilku tylko wybranych zastosowaniach analizy dyskursu lekcyjnego. Bez względu jednak na wybór którejkolwiek z wymienionych wyżej opcji i niezależnie od usytuowania w środowisku akademickim bądź nauczycielskim, neofilolog zainteresowany dyskursem na lekcji języka obcego powinien dążyć do zebrania danych o odpowiednich parametrach jakościowych i ilościowych. Czy będzie to badanie w działaniu mające wspomóc 
doskonalenie własnego warsztatu zawodowego poprzez obserwację uczestnicząca, czy też przygotowywanie rozprawy naukowej opartej na podejściu etnograficznym lub studium przypadku, niezbędne okażą się obserwacje i rejestracje, które potem wymagać będą wielu godzin pracy redakcyjnej i analitycznej.

Analiza dyskursu edukacyjnego to przede wszystkim żmudne gromadzenie i interpretowanie danych. Same konspekty lekcji ze scenariuszami wypowiedzi sporządzone na podstawie notatek obserwacyjnych nie wystarcza, chociaż będą niewątpliwie bardzo przydatne podczas dalszych działań. Okazuje się, że właściwy materiał badawczy zebrać można wyłącznie w wyniku ,terenowej” rejestracji lekcji i następnie „gabinetowego" opracowania korpusu danych, najlepiej w postaci fachowych transkrypcji.

Badacz może zamierzać dokonać nagrań filmowych lub tylko dźwiękowych, ale w każdym wypadku będzie musiał rozwiązać wiele problemów natury nie tylko technicznej, lecz także etycznej i prawnej. Po pierwsze, zastosowany sprzęt musi być bardzo dobrej jakości, jeśli dane sprowadzone do postaci pisemnej maja możliwie wiernie odtworzyć przebieg zarejestrowanej interakcji ustnej. Jednak mimo użycia nawet najlepszej technologii, należy liczyć się z bardzo niekorzystnym przelicznikiem czasowym podczas obróbki surowego materiału: każda minuta nagrania to w efekcie co najmniej kilkanaście minut pracy nad transkrybowaniem dyskursu. Po drugie, jakiekolwiek rejestracje wymagają oczywiście wcześniejszej wiedzy i zgody uczestników interakcji lekcyjnej, nie mówiąc o powiadomieniu władz szkoły oraz rodziców zwłaszcza młodszych uczniów. Poza tym, jeśli nawet uda się badaczowi pokonać skądinąd zrozumiały opór osób nagrywanych oraz ich mocodawców bądź opiekunów, to i tak najprawdopodobniej nie sposób będzie całkowicie wyeliminować tzw. paradoksu obserwatora (por. Labov 1970), a więc stopnia, w jakim sama obecność kogoś z zewnątrz, a także mikrofonów i kamer, zmienia zwyczajowe zachowanie uczniów i nauczyciela. Po trzecie wreszcie, trzeba zagwarantować uczestnikom rejestracji poczucie bezpieczeństwa. Nie chodzi tu tylko o standardową anonimowość poszczególnych kwestii rozpisanych w transkrypcjach, ale przede wszystkim o ochronę dobrego imienia osób, które użyczają badaczowi swojego głosu i/lub wizerunku, i które muszą mieć pewność, że utrwalony materiał nie dostanie się w niepowołane ręce.

\section{Transkrypcje jako typowe formy zapisu przetworzonych danych}

Transkrypcja interakcji lekcyjnej oparta bywa na wzorcu wywodzącym się z analizy konwersacyjnej, wszakże często bez charakterystycznej dla podejścia lingwistycznego szczegółowości czasowej i prozodycznej. Odpowiednie konwencje dobrze ilustruje poniższy zapis (Piotrowski 2006: 176-177), przedstawiony tu we fragmencie początkowym. Widzimy w nim charakterystyczne zabiegi redakcyjne takie jak:

- $\quad$ podział dyskursu na poszczególne role ( $\mathrm{E}=$ nauczyciel; pozostałe inicjały = uczniowie; Ax = uczeń niezidentyfikowany); 
- ponumerowanie kolejnych wypowiedzi w skrajnej lewej kolumnie; jest to konwencja bardzo przydatna w dyskusji, kiedy można precyzyjnie odnieść się do odpowiedniego miejsca w tekście;

- oznaczenie pauz (znak +);

- wskazanie skrótów za pomocą wielokropka umieszczonego między nawiasami kwadratowymi;

- oszczędne stosowanie znaków interpunkcyjnych, aby jak najwierniej oddać ustny charakter dyskursu;

- pominięcie dużych liter (z wyjątkiem tytułów i nazw własnych) - w tym samym celu;

- operowanie emfazą dla wyróżnienia wypowiedzi w języku pierwszym (J1);

- opisanie komunikacji niewerbalnej oraz innych 'didaskaliów' kursywa w nawiasach kwadratowych (wybrany tu język francuski jest zarazem językiem całej pracy).

1 E sujet « L'arbre généalogique. » nous allons analyser l'arbre généalogique du monsieur Dupuis

$2[\ldots]$

3 E vas- $\mathrm{y}+$ cinq personnes cinq personnes d'accord il $\mathrm{y}$ a ta ta mère ton père toi

4 KI frère

5 E un frère il s'appelle comment ? ton frère

6 KI Mateusz [très bas]

7 E plus fort parce qu'on n'entend pas + Mateusz oui ? et la sœur elle s'appelle

8 KI Eliza

9 E un frère une sœur [E écrit au tableau $]$

10 Ax jakiego to jest rodzaju ?

11 E un frère jak myślisz ?

12 Ax męskiego ?

13 E oui c'est masculin donc c'est un frère ça c'est féminin donc c'est une sœur

14 E Arek tu as des frères et sœurs?

15 AR et oui j’ai un frère

16 E un frère tu n'as pas de sœur pas de sœur

17 AR uhm oui

18 E si ?

19 AR si / nie / oui [rires $]+$

20 AR nie mam

21 E non je n'ai pas de sœurs

Przedstawiony powyżej zapis wypowiedzi ma standardowy układ pionowy, który niewiele różni się od systemu obowiązującego w innych gatunkach tekstu, na przykład w dramacie czy wywiadzie. Jest to transkrypcja odpowiednia dla interakcji z udziałem wielu uczestników, a więc na przykład komunikacji angażującej nauczyciela i całą klasę. Jednym $z$ alternatywnych sposobów transkrybowania dyskursu jest układ kolumnowy, który szczególnie dobrze oddaje strukturę interakcji w małej grupie. W przeciwieństwie do układu standardowe- 
go, daje on badaczowi możliwość szybkiego prześledzenia ilościowych i jakościowych aspektów udziału poszczególnych uczestników. Przykład takiego zapisu przedstawiono poniżej (za Swann 2001: 333). Niektóre rozwiązania zredagowane zostały inaczej, niemniej używa się ich równie często co tych z poprzedniej transkrypcji. Poza tym kilka konwencji występuje tu po raz pierwszy, natomiast pozostałe różnice między systemami są mniej istotne:

- Oznaczenie uczestników interakcji anonimowo jako Girl 1 (G1), Boy 1 (B1) itd.; język angielski jest zarazem językiem artykułu;

- $\quad$ ponumerowanie kolejnych wierszy zapisu zamiast kompletnych wypowiedzi;

- zapisanie pauz jako znak (.);

- wykaz niepewnych lub niezrozumiałych fragmentów wypowiedzi w nawiasach okragłych - np. (would) lub ( ); przy nanoszeniu zapisu odsłuchiwanych wypowiedzi na arkusz transkrypcyjny straty informacji sa nieuniknione;

- oznaczenie kwestii przypisanych domyślnie danemu rozmówcy przez znak (?);

- zastosowanie dużej litery wyłącznie do zasygnalizowania początku wypowiedzi (nie licząc zaimka osobowego 'I'), przy czym kwestie wtrącone przez innych uczestników zapisane są z małej litery;

- oddzielenie notatek scenariuszowych i obserwacyjnych (skrajna prawa kolumna) od informacji na temat komunikacji niewerbalnej (patrz komentarz umieszczony między nawiasami ostrokątnymi bezpośrednio w zapisie rozmowy - wiersze 6 i 7).

$\begin{array}{llll}\text { G1 } & \text { G2 } & \text { B1 } & \text { B2 }\end{array}$

1 What are we going

2 to do at home

(.)

3 any idea

4

5

6

7

8

9

10

11
Yes (.) I take

this (.) I take

this < general

laughter $>$ yes

yes

I take it

mmmh

and I see and I

see

if there's

something I

can

use (.)
Notes

addresses

group

directly

refers to

book

which he

holds

up 
13 We can use

(?)

14

15

16

17

18

19

20

21

22

23

24

25

26

27

28

29
We can use

$\begin{array}{ll}\begin{array}{l}\text { So what } \\ \text { (would) }\end{array} & \text { question } \\ \text { we do () read } & \begin{array}{l}\text { towards } \\ \text { girls? }\end{array} \\ \text { it at home (.) } & \\ \text { the questionna- } & \\ \text { ire } & \end{array}$

(.) read it at

home
[...]

Maybe I can

get

some mate-

rials

for this

From

(mother)

Yes

from my

mother

(.) from the

travel agency

from where (?)

Powyższy przykład, przytoczony wiernie za oryginałem, mógłby z pewnościa być bardziej przejrzysty, gdyby wszelkie komentarze zredagowane zostały inaczej (np. kapitalikami; por. dalsze przykłady) niż zapis samej interakcji. Pamiętajmy jednak o tym, że istnieje jeszcze wiele innych sposobów przedstawiania dyskursu lekcyjnego w postaci transkrypcji, dających badaczowi możliwość kompilowania własnych systemów w zależności od gatunku tekstu i celu analizy. Taką mieszaną postać mają zresztą transkrypcje zamieszczone w dalszej części niniejszego artykułu. Można zaryzykować pewne uproszczenie, że im bardziej metodyczny, szkoleniowy charakter zapisu, tym rzadziej wypadnie sięgać po lingwistyczne konwencje odbiegające od „zwyczajnego” przedstawiania przebiegu konwersacji. Najważniejsze, aby czytelnik podręcznika, artykułu czy pracy magisterskiej otrzymał od autora rzetelny opis zastosowanych rozwiązań redakcyjnych w postaci dokładnego klucza.

\section{Przykładowe aplikacje analizy dyskursu lekcyjnego}

Po przedstawieniu sposobów sporządzania transkrypcji przejdźmy do omówienia różnych zastosowań analizy dyskursu edukacyjnego w realizacji szczegółowych celów badawczych. Częstą aplikacją jest śledzenie tak ważnej funkcji połą- 
czonej interakcji i dydaktyki, jaka jest udzielanie informacji zwrotnej przez nauczyciela. Posłużymy się tu dwoma przykładami, które pochodzą z lekcji języka polskiego jako języka drugiego (J2) z udziałem uczniów anglojęzycznych.

W pierwszej transkrypcji nauczyciel trzykrotnie rezygnuje $z$ wdrożenia tradycyjnego mechanizmu naprawczego (eksplicytna korekta bezpośrednia) i decyduje się na przeformułowanie (ang. recast; Lyster i Ranta 1997) błędnych wypowiedzi osób uczących się, tak aby jednocześnie zaproponować poprawny model i zarazem podtrzymać dobrze rozwijającą się dyskusję. Te reakcje nauczyciela, które zawierają korekcyjną informację zwrotną zostały wyróżnione emfazą (wypowiedzi 3, 5 i 7).

1 N Dlaczego człowiek szuka towarzystwa zwierząt?

2 U1 Bo zwierząt są dobre przyjaciele dla-- dla człowieków.

3 N Zgoda, zwierzęta to nasi dobrzy przyjaciele, PRZEFORMULOWANIE przyjaciele ludzi.

$4 \quad$ U2 Jeszcze oni zawsze są szczęśliwie ciebie zobaczyć.

5 N Czyli one cieszą się, kiedy nas widzą, tak? (.) No PrZEFORMUŁOWANIE bo ja wiem? Pies, kot to może. (.) Ale taki wąż na przykład? (..)

6 U1 Oni też nie są za dużo kłopotu.

7 N No tu bym się nie zgodził. One jednak czasem PrZeformulowanie sprawiają kłopoty. Z psem=

$8 \quad$ U1 =Ja mam-- canary. W ogóle-- ona nie jest taki duży problem.

Jak możemy wnioskować z analizy zapisu, funkcja interakcyjna przeformułowań zrealizowana została pomyślnie, natomiast nie możemy tak jednoznacznie ocenić efektywności dydaktycznej funkcji wybranej formy implicytnej informacji zwrotnej. Po pierwsze, brak jest dowodów na skuteczne przejęcie takiej informacji (ang. uptake; Lyster i Ranta 1997) przez uczniów, ponieważ nie zareagował na nią - na przykład w formie autokorekty - ani U1 w wypowiedzi 4, ani U2 w wypowiedzi 6. Po drugie zaś, w wypowiedzi 8 U1 popełnił podobny błąd jak w swojej poprzedniej kwestii, która dopiero co została przez nauczyciela przeformułowana. Reasumując, analiza badanego fragmentu dyskursu lekcyjnego każe ostrożnie oceniać przydatność korekty implicytnej, której walory interakcyjne moga nie rekompensować strat, jakie ponosi dydaktyka, jeśli osoba ucząca się nawet nie zauważa elementów naprawczych informacji zwrotnej.

Zupełnie inną strategię poprawiania błędów obserwujemy w kolejnej transkrypcji. Nauczyciel zareagował na tylko jedną nieprawidłowość w dłuższej wypowiedzi uczennicy, za to wybrał eksplicytny sposób udzielania negatywnej informacji zwrotnej, jakim jest negocjowanie formy. Porównajmy:

1 U Miałam dobra, ale histeryczna psa, Brittany, kiedy byłam młoda. (.) Codziennie, kiedy przyszłam ze szkole do domu, Brittany normalnie zaczynała 


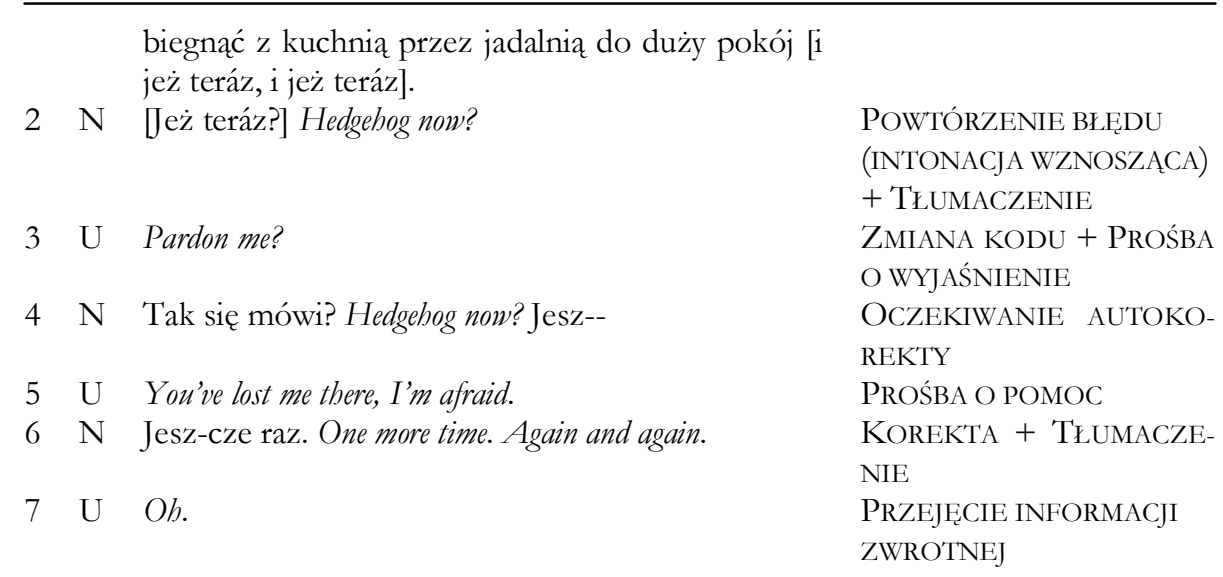

Jak widać, realizacja celu naprawczego, bardzo zresztą tradycyjna, z zaangażowaniem nie tylko powtórzenia błędu (wypowiedź 2), lecz również jego dosłownego tłumaczenia na J1 uczennicy (wypowiedzi 2 i 4), a w końcu także korekty i tłumaczenia poprawnego (wypowiedź 6), jest skuteczna w sensie pedagogicznym, jako że uczennica wydaje się rozumieć wywód nauczyciela (wypowiedź 7). Z drugiej jednak strony, w sensie interakcyjnym i socjopragmatycznym, klimat konwersacji jest zupełnie inny niż w przykładzie poprzednim. Po pierwsze, swobodna wymiana informacji musi ustapić metakomunikacji, a więc rozmowie o języku. Po drugie, nieskutecznym tłumaczeniem w wypowiedzi 2 nauczyciel doprowadza do zmiany kodu, co kłóci się ze strategicznym celem nauczania sprawności mówienia w J2. Po trzecie wreszcie, uczennica odbiera wypowiedzi 2 i 4 nauczyciela jako akty zagrażające twarzy, co z kolei wprowadza do interakcji niepotrzebne napięcie. Podsumowując wszystkie te uwagi, stwierdzamy, że mimo skuteczności korekty, omawiany typ realizacji funkcji naprawczej w dyskursie lekcyjnym wydaje się ryzykowny z interakcyjnego punktu widzenia.

Wspomniana wyżej metakomunikacja także dostarcza cennego materiału badaczom dyskursu edukacyjnego. Jest częścią mowy nauczyciela, a w wydaniu ekstremalnym przybiera postać mini-wykładów w J1 na temat gramatyki bądź leksyki J2. A oto przykład (Lęska 2007: 113; z niewielkimi modyfikacjami):

N3 Aha, dobrze. [NAUCZYCIEL ZAPISUjE ZDANIE Z CZASOWNIKIEM asked NA TABLICY] Asked to jest czasownik, mamy formę bezokolicznika, to help, a między nimi wcisnął się jeszcze, wcisnęło się jeszcze dopełnienie, osoba: poprosiła kogo? Poprosiła mnie. I wtedy po tym dopełnieniu będzie bezokolicznik ... Jeżeli jest to w formie bezokolicznikowej, to ona, ta forma, musi mieć to. Jest kilka wyjątków, po których będzie stał sam czasownik bez to. 
Treść - ale niekoniecznie forma - powyższej wypowiedzi przypomina nam o tym, że jesteśmy na lekcji języka obcego, który jest tu wprawdzie obecny, ale zaledwie jako kod cytowany. Podobnie pod względem nadreprezentacji J1 przedstawia się dyskurs między nauczycielem a uczennicą w następnym fragmencie transkrypcji materiału lekcyjnego (Piotrowski 2006: 184). Tym razem interakcja dotyczy trudności w realizacji zadania leksykalnego:

$11 \mathrm{Ax} \quad[a ̀$ E pendant le travail en binômes $]$ jak jest « solarium "?

12 E a co to jest solarium ?

13 Ax takie miejsce w którym można się opalić właśnie bez... / takie sztuczne słońce

14 E tu peux employer le mot solarium

15 Ax a samoopalacz?

16 E opalać c'est bronzer

17 Ax a samoopalacz?

18 E zastanów się co to jest i wtedy będziesz wiedziała

$19 \mathrm{E}$ [à tout le groupe] ça va? vous êtes prêts?

Jak widać, brak ściślejszego określenia ról J1 i J2 w klasowym dyskursie bilingwalnym prowadzi do tego, że J1 wypiera J2 z prostych funkcji interakcyjnych, przy czym zmiana kodu zainicjowana przez uczennicę w celu metakomunikacyjnym w wypowiedzi 11 zostaje przez nauczyciela zaakceptowana (wypowiedzi 12, 16, 18). Analiza nie tylko tych dwóch ostatnich przykładów dyskursu lekcyjnego potwierdza powszechne spostrzeżenia obserwacyjne: metamowa w J1 najbardziej zbliża dydaktykę języka obcego do interakcji na lekcjach innych przedmiotów szkolnych.

Rola języka ojczystego w komunikacji na lekcji języka obcego to kolejny temat odpowiedni dla analizy dyskursu edukacyjnego. Ogólne wrażenie, jakie wynieść można z bezpośrednich obserwacji lekcji sprowadza się na ogół do stwierdzenia, że nauczyciele i uczniowie używają J1 dość często, być może nawet zbyt często. Dopiero w transkrypcjach nagrań odkryć można intrygujące prawidłowości i zależności, które skłaniają badacza do bardziej powściąliwych wniosków. Spójrzmy dla przykładu na poniższy wyciąg z zapisu typowej lekcji języka angielskiego w naszych warunkach szkolnych (Majer 2003: 402):

1 T: OK, so I want you to listen to the recording and as you listen you must match these musicians you can see in the book with their country of origin. Is it clear to everybody?

2

3

4

5

6

7
T: Are you sure? Wojtek, co mamy zrobic?

T: Dobrze, ale co trzeba zrobićpo stuchaniu?

T: That's it. Perfect, Marcin.
Ss: Yes.

S1: No, postuchać tego listeningu i ten, no--

S2: Dopasowaí nazwiska muzyków do krajów pochodzenia. 
Z inicjatywy nauczyciela dochodzi tu wprawdzie do zmiany kodu (wypowiedź 3), ale manewr ten spowodowany jest zamiarem upewnienia się, czy uczniowie dobrze zrozumieli polecenie wydane w J2 (wypowiedź 1). Taki „,konsultacyjny", dygresyjny dyskurs w J1 występuje dość często właśnie przy realizacji proceduralnych celów kierowania klasą, np. wdrażania aktywności, organizowania pracy w grupach, czy dyscyplinowania uczniów. Po osiagnięciu zamierzonego celu przez nauczyciela dyskurs wraca do swojej pierwotnej postaci, czyli komunikacji w J2 (wypowiedź 7). Oba języki mają tu swoje z góry wyznaczone role.

Zupełnie inaczej przedstawia się relacja między J2 i J1 w kolejnej próbce analizy interakcji lekcyjnej (Majer 2003: 406):

T: Głośno, chtopaki: 'Bedroom'. Wyraźnie, and you girls. I co to jest?

Co prawda, funkcja mowy nauczyciela jest tutaj podobna, ale brak jest klarownej organizacji dyskursu w zakresie wyboru języka. Pomijając implikacje metodyczne i oceniając powyższy zapis wyłącznie w kategoriach socjolingwistycznych, musimy stwierdzić, iż nauczyciel przełącza się z J1 na J2 i z powrotem bez jakiegoś sensownego planu. Kolejnością wystąpienia języków, długością wypowiedzi w tym samym kodzie oraz momentem zmiany kodu zdaje się rządzić przypadek.

Zilustrowane powyżej zachowanie nie jest bynajmniej domeną tylko mowy nauczyciela. Dyskurs bilingwalny na lekcji języka obcego powstaje oczywiście także dzięki udziałowi osób uczących się. Ale mechanizm wyboru języka i zmiany kodu nie musi być tak zagadkowy jak w poprzednim przypadku. Na przykład w zamieszczonym poniżej fragmencie (Majer 2003: 412) obserwujemy związana z przełączaniem się na J1 funkcją strategiczną wypowiedzi ucznia (zdania wyróżnione kursywą w nr 3):

1

2 T: (GESTURES REQUESTING SELFCORRECTION)

3

4 T: 'Apply'. 'Apply for a visa'.
S: I will be stay in Sweden uh when finish holidays.

S: No, kiedy sie skończq wakacje. Because I-- in the Swedish Ambassady [sic. Embassy] must to-- Jak jest 'zł ło żyć?

W pierwszym przypadku uczeń reaguje zmianą kodu na niewerbalną informację zwrotną nauczyciela, z tym że zamiast autokorekty otrzymujemy tłumaczenie. Można tę postawę potraktować jako strategię unikania ryzyka. Natomiast w drugim przypadku obserwujemy typową dla kontekstów instytucjonalnych strategię odwołania się do autorytetu, realizowaną jako prośbę o podanie słownikowego odpowiednika w J1 wyrazu niezbędnego dla ukończenia wypowiedzi w J2.

Ostatnim przykładem zastosowania analizy dyskursu na lekcji języka obcego omawianym w niniejszym artykule będzie typologia pytań nauczycielskich. 
Można ten temat rozpatrywać w kategoriach konwersacyjnych i badać zależność między czasem danym uczniowi do namysłu a długością i jakością jego odpowiedzi. Z kolei interakcjoniści chętnie doszukują się związków między rodzajem pytań stawianych uczniom a przyrostem ich kompetencji komunikacyjnej dzięki zabiegom wspomagania dyskursu przez modyfikację danych wejściowych i negocjowanie znaczenia. Jeszcze inny wybór to potraktowanie zagadnienia jako problem metodyczny w ramach podejścia komunikacyjnego do dydaktyki języka obcego, a więc zalecanie nauczycielom i studentom neofilologii zadawania tylko takich pytań, które nie określają odpowiedzi z góry i które dają uczniowi możliwość rozwinięcia wypowiedzi. W ostatnich dekadach opublikowano na ten temat wiele ważnych prac (np. Mehan 1979; Long i Sato 1983; Rowe 1987; Spada i Lightbown 1993; Nunn 1999; Basturkmen 2001; Guang Eng Ho 2005).

Okazuje się jednak, że precyzyjne ustalenie nie tylko gatunków pytań, ale także ich potencjału interakcyjnego nie jest wcale takie proste. Dopiero skrupulatne przestudiowanie transkrypcji lekcyjnych pozwala badaczowi na dokładniejsze określenie aspektów ilościowych i jakościowych dyskursu, jaki powstaje w wyniku sterowania komunikacją za pomocą różnych typów pytań. Przyjrzyjmy się bardzo charakterystycznemu przykładowi (Majer 2003: 251):

1 T: OK. And what's the weather like today. (PAUSES TO SELECT STUDENT) Gosia?

S3: It's uh the sun shining. It's nice day.

S3: It's fine weather today.

T: OK. And Maciek, what are your plans for today? For the whole weekend?

S4: I will be learn.

S4: Maybe too.

S5: It's Friday.

S6: It's (PAUSE) nineteen March.

S6: The nineteenth of March.

Zgodnie z klasycznym podziałem typologii pytań lekcyjnych na mniej pożądane pokazowe (ang. display questions; por. Long i Sato 1983) i bardziej przez metodyków zalecane referencjalne (ang. referential questions), powyższy dyskurs wydaje się preferować te drugie. Czy jednak zyskuje na tym jakość interakcji? Wątpliwe wydaje się na przykład, czy w wypowiedziach 5 i 7 nauczyciel jest naprawdę zainteresowany planami 
ucznia na nadchodzący weekend, podczas gdy pytania zadane w wypowiedziach 1 i 9 najprawdopodobniej służą jedynie typowej rozgrzewce i podtrzymaniu rozmowy. Ponadto, jeśli przyjrzymy się udziałowi klasy w zapisie uwidocznionym w prawej kolumnie transkrypcji, to zauważymy, iż uczniowie wnieśli do rozmowy mniej niż nauczyciel. Nie dość, że ich odpowiedzi są stosunkowo krótkie $(6,8,10)$, to jeszcze mamy tu powtórzenia korekty nauczycielskiej (4 i 14). W rezultacie, mimo pozorów autentyczności, komunikacja jest mocno strywializowana.

Dla kontrastu warto zanalizować ostatnią z proponowanych transkrypcji. Pytania zadane przez nauczyciela sprawiaja, że jest to sytuacyjnie i treściowo dyskurs bardzo podobny do poprzedniego, z tą tylko różnica, że komunikacja zdaje się być bardziej autentyczna. Świadczy o tym nawet korzystanie z zasobów $\mathrm{J} 1 \mathrm{w}$ kilku przypadkach zmiany kodu, i to zarówno przez nauczyciela (wypowiedź 1), jak i ucznia $(4,8,10,12)$, chociaż ostatecznie uczeń zostaje zdyscyplinowany (wypowiedzi 11 i 13). Z drugiej strony, trudno byłoby wskazać inne konkretne cele pedagogiczne realizowane w poszczególnych wymianach. Czy chodzi o negocjowanie znaczenia, czy może o negocjowanie formy? Porównajmy (Majer 2008: 90-91):

$1 \mathrm{~T}$ When you meet at home, when you meet after school, jak po szkole sie spotykacie, after school.

2 S Uh--

3 T What do you do?

4 S No uh no, robimy różne rzeczy, rozmawiamy--

5 T Yeah, so you walk.

6 S And talk.

7 T And talk.

8 S Znaczy talk, my nie chodzimy.

9 T You don't walk.

$10 \mathrm{~S}$ Yes, czytamy gazety.

$11 \mathrm{~T}$ In English.

$12 \mathrm{~S}$ Read czasopisma.

13 T Magazines.

14 S Magazines.

$15 \mathrm{~T}$ Mhm, so you read magazines.

Kolejnym argumentem, który świadczyłby o bardziej swobodnym charakterze interakcji jest fakt, iż mechanizm naprawczy obsługiwany jest przez obie strony (wypowiedzi ucznia: $6,8,10,12$, wypowiedzi nauczyciela: 13,15$)$. Jak jednak nietrudno zauważyć, nawet taki mniej przewidywalny dyskurs nie jest wolny od dominacji nauczyciela, któremu przysługuje z kolei wyłączne prawo zadawania pytań. Efektem końcowym jest rozmowa oparta na pytaniach referencjalnych, która prowadzi do bardziej naturalnej wymiany informacji, ale za cenę niejasności celów interakcyjnych i pedagogicznych. Trudno zatem powiedzieć, czy w porównaniu ze sztucznością pokazowych pytań dyskursu z poprzedniej transkrypcji aż tak wiele zyskała jakość komunikacji odbywającej się w instytucjonalnym kontekście, jakim jest klasa szkolna. 


\section{Podsumowanie}

Powyższe rozważania z natury rzeczy nie wyczerpują dyskusji na temat technicznych uwarunkowań pobierania danych i możliwych zastosowań analizy dyskursu na lekcji języka obcego. Czytelnik zainteresowany poruszaną w artykule tematyką powinien koniecznie sięgnąć po źródła, które rozszerzą stosunkowo wąski, specjalistyczny zakres problemowy o treści bardziej ogólne, szczególnie te dotyczące lingwistycznej analizy dyskursu i sposobów prowadzenia badań. Z książkowych pozycji dostępnych w wersji polskojęzycznej polecić warto zbiór studiów na temat strukturalnych i procesowych aspektów dyskursu autorstwa Teuna van Dijka (2001) oraz praktyczny poradnik badacza-obserwatora napisany przez Edwarda C. Wragga (2001). Prace te uzupełnić można o lekturę w wersji anglojęzycznej, na przykład tak wartościowe podręczniki jak monografia Heidi Riggenbach (1999) o dyskursie na lekcji języka obcego, wprowadzenie do metodologii badań autorstwa Jamesa Deana Browna i Theodore S. Rodgersa (2002) oraz poradnik dla nauczyciela zainteresowanego badaniami w działaniu napisany przez Donalda Freemana (1998) - wszystkie z zadaniami do rozwiązania i bogatymi aneksami. Dopiero w oparciu o literaturę przedmiotu można będzie odpowiednio uzasadnić cel działań empirycznych oraz fachowo zaplanować ich przebieg.

\section{BIBLIOGRAFIA}

Basturkmen, H. 2001. „Descriptions of spoken language for higher level learners: The example of questioning". ELT Journal 55. 4-13.

Bellack, A. A., Kliebard, H. M., Hyman, R. T. i Smith Jr., F. L. 1966. The language of the classroom. Final report, USOE Cooperative Research Project, No. 2023. New York: Teachers College Press, Columbia University.

Bernstein, B. 1990. Class, codes and control, Vol. 4: The structure of pedagogic discourse. London: Routledge.

Brown, J. D. i Rodgers, T. S. 2002. Doing second language research. Oxford: Oxford University Press.

Candlin, C. C. i Mercer, N. (red.). 2001. English language teaching in its social context. $A$ reader. London: Routledge.

Cazden, C. B. 1988. Classroom discourse. The language of teaching and learning. Portsmouth, NH: Heinemann.

Freeman, D. 1998. Doing teacher research: From inquiry to understanding. Pacific Grove: Heinle \& Heinle Publishers.

Guan Eng Ho, D. 2005. „Why do teachers ask the questions they ask?”. RELC Journal 36. 297-310.

Labov, W. 1970. Sociolinguistic patterns. Oxford: Basil Blackwell.

Long, M. H. i Sato, C. J. 1983. „Classroom foreigner talk discourse: Forms and functions of teachers' questions”, w: Seliger, H. W. i Long, M. H. (red.). 1983. 268-285. 
Lyster, R. i Ranta, L. 1997. „Corrective feedback and learner uptake”. Studies in Second Language Acquisition 19. 37-66.

Łęska, K. 2007. „Metamowa' na lekcjach języka angielskiego”, w: Majer, J. i Nijakowska, J. (red.). 2007. 109-127.

Łęska, K. 2008. Teachers' use of interaction patterns in a foreign language classroom and gains in students' oral fluency. Częstochowa: Wydawnictwo Wyższej Szkoły Lingwistycznej.

Majer, J. 2003. Interactive discourse in the foreign language classroom. Lódź: Wydawnictwo Uniwersytetu Łódzkiego.

Majer, J. 2008. „Negotiation of form in foreign-language classroom discourse”, w: Pawlak, M. (red.). 2008. 79-94.

Majer, J. i Nijakowska, J. (red.). 2007. Jezylk - Poznanie - Zachowanie. Studia nad psycholingwistycznymi aspektami prayswajania jezylka. Łódź: Wydawnictwo Uniwersytetu Lódzkiego.

Mehan, H. 1979. „'What time is it, Denise?'. Asking known information questions in classroom discourse". Theory into Practice 18. 285-294.

Niżegorodcew, A. 2007. Input for L2 learners. The relevance of relevance. Clevedon: Multilingual Matters.

Nunn, R. 1999. "The purpose of language teachers' questions”. IRAL 37. 23-42.

Pawlak, M. 2004. Describing and researching interactive processes in the foreign language classroom. Konin: Wydawnictwo Państwowej Wyższej Szkoły Zawodowej w Koninie.

Pawlak, M. (red.). 2008. Investigating English language learning and teaching. Poznań - Kalisz:

Wydawnictwo Wydziału Pedagogiczno-Artystycznego UAM w Kaliszu.

Pica, T. 1996. „Do second language learners need negotiation?”. IRAL 34. 1-21.

Piotrowski, S. 2006. Gestion des tâches et mode d'accés à la langue. Lublin: Towarzystwo Naukowe KUL.

Riggenbach, H. 1999. Discourse analysis in the language classroom. Volume 1. The spoken language. Ann Arbor: The University of Michigan Press.

Rowe, M. B. 1987. „Using wait time to stimulate inquiry”, w: Wilen, W. W. (red.). 1987. 102-109.

Sarangi, S. i van Leeuwen, T. (red.). 2003. Applied linguistics and communities of practice. London: Continuum.

Seedhouse, P. 2004. „The interactional architecture of the language classroom: A Conversation Analysis perspective". Language Learning Monograph Series 4. 1-272.

Seliger, H. W. i Long, M. H. (red.). 1983. Classroom-oriented research in language learning. Rowley, MA: Newbury House.

Sinclair, J. i Brazil, D. 1982. Teacher talk. Oxford: Oxford University Press.

Sinclair, J. i Coulthard, M. 1975. Towards an analysis of discourse: The English used by teachers and pupils. London: Oxford University Press.

Spada, N. i Lightbown, P. M. 1993. „Instruction and the development of questions in L2 classrooms". Studies in Second Language Acquisition 15. 205-224.

Swann, J. 2001. „Recording and transcribing talk in educational settings”, w: Candlin, C. C. i Mercer, N. (red.). 2001. 323-344. 
van Dijk, T. 2001. Dyskurs jako struktura i proces. Warszawa: Wydawnictwo Naukowe PWN.

van Lier, L. 1984. „Analysing interaction in second language classrooms”. ELT Journal 38. 160-169.

Wilen, W. W. (red.). 1987. Questions, questioning techniques, and effective teaching. West Haven, CT: NEA Professional Library.

Wragg, E. C. 2001. Co i jak obserwować w klasie? Warszawa: Wydawnictwo Akademickie „Żak”. 